\title{
Beauveria Bassiana Applied to Broiler Chicken Houses as Biocontrol of Alphitobius Diaperinus Panzer (Coleoptera: Tenebrionidae), an Avian Pathogens Vector
}

-Author(s)

\author{
Alves LFA' \\ Oliveira DGPI \\ Lambkin T"II \\ Bonini $A K^{\prime}$ \\ Alves $V^{\prime}$ \\ Pinto FGS' \\ Scur $\mathrm{MC}^{\prime}$
}

State University of Western Paraná Laboratory of Agricultural Biotechnology, Rua Universitária, 2069, 85814110, Cascavel, Paraná, Brazil

" Federal University of Technology/UTFPR Rua Cerejeira, 85892000, Santa Helena, Paraná, Brazil

II' Entomologist at Ensource Consulting Pty Ltd, 10 Gregory Street, Taringa, Brisbane, Queensland 4068, Australia

\section{nMail Address}

Corresponding author e-mail address Luis F. A. Alves

State University of Western Paraná, Laboratory of Agricultural Biotechnology, Rua Universitária, 2069, 85814110, Cascavel, Paraná, Brazil.

Email: luis.alves@unioeste.br

\section{EKeywords}

Animal production, biological control, entomopathogenic fungi.

\section{ABSTRACT}

Beauveria bassiana is naturally found in broiler chicken houses, and has been shown to be active against the lesser mealworm, Alphitobius diaperinus. The effectiveness of soil application of $B$. bassiana in emulsifiable oil-type formulation (Unioeste 4 isolate) to control the lesser mealworm in commercial poultry house was evaluated. The fungus was applied to the dirt floor of poultry house at $4.2 \times 10^{9}$ conidia $/ \mathrm{m}^{2}$ (treated aviary) and the insect population was assessed before and 96, 146 and 216 days after application (DAA). In the control aviary, no treatment was performed to control those insects. Molecular techniques were used to confirm the presence of the fungus in dead $A$. diaperinus. Significant treatment effects were observed, with $56 \%$ and $73 \%$ of insect population reduction on 96 and 146 DAA, respectively. However, on 216 DDA, insect population resumed to values close to those initially observed. In the control aviary, the population grew steadily, reaching almost $110 \%$ the initial population on 96 DAA, and close to $200 \%$ on 216 DDA. The results demonstrate the potential of the applied control strategy, even with a single application of the fungus; however, reapplications may be required after 3-6 months for more effective control.

\section{INTRODUCTION}

The lesser mealworm Alphitobius diaperinus (Panzer) (Coleoptera: Tenebrionidae) is a ubiquitous and significant insect pest in commercial poultry house litter. The young chicks ingest larval and adult of the lesser mealworms, which negatively affects their performance and behavior, and causes gastrointestinal lesions (Despins \& Axtel, 1995; Japp, 2008). The insect plays a potential role as vector of viruses, protozoa (Eimeria), and bacteria (Campylobacter and Clostridium) (Goodwin \& Waltman, 1996; Skov et al., 2004). The beetle is also the intermediate host for the nematode Hadjelia truncata (Alborzi \& Rahbar, 2012) and it is a vector of Salmonella (Segabinazi et al., 2005; Vittori et al., 2007; Hazeleger et al., 2008; Roche et al., 2009; Chernaki-Leffer et al., 2010).

The control of $A$. diaperinus is based on poultry house management practices and chemical insecticides, mainly pyrethroids, which are applied to the internal surfaces of the facilities and poultry litter (Bellaver et al., 2003; Lambkin et al. 2012). However, despite the initial population reduction, these insecticides have proven to be ineffective (Uemura et al., 2008; Santos et al., 2009).

Alternative control measures under study include insecticidal plants, inert powders (hydrated lime and diatomaceous earth) and entomopathogenic nematodes (Watson et al., 2003; Marcomini et 
al., 2009; Alves et al., 2012; Lambkin et al., 2012). There are several reports on natural occurrence of entomopathogenic fungi infecting $A$. diaperinus in aviaries in Brazil and the United States, and on the selection of isolates against this pest, specially Beauveria bassiana (Hypocreales: Cordycipitaceae) and Metarhizium anisopliae (Hypocreales: Clavicipitaceae) (Steinkraus et al., 1991; Geden et al., 1998; Alves et al., 2004, 2005; Rohde et al., 2006; Chernaki-Leffer et al., 2007b; Santoro et al., 2008; Oliveira et al., 2011).

Despite the high mortality observed in laboratory, the use of $B$. bassiana is limited by product formulation, the physicochemical characteristics of the surface treated (cardboard tube traps, soil or litter), and application methods (Geden et al., 1998; Alexandre et al., 2006; Alves et al., 2008; Gazoni et al., 2011). In addition, poultry litter is rich in ammonia, which has strong fungistatic action, affecting the germination of different fungal species (Bacon, 1986). Previous studies showed that application of a $B$. bassiana emulsifiable oil formulation to poultry litter caused only $40 \%$ mortality of lesser mealworm adults (Crawford et al., 1998). The use of $B$. bassiana for lesser mealworm control in poultry houses has been discouraged (Geden et al., 1998). However, under laboratory conditions, a $B$. bassiana isolate formulated in a dry powder was more efficient when applied on poultry house soil than when applied on poultry litter (Alves et al., 2008). Soil application is also recommended for the chemical control of the lesser mealworm due to its efficacy and safety (Uemura et al., 2008; Santos et al., 2009).

Soil is the natural ecosystem of $B$. bassiana, and poultry houses provide appropriate temperature and moisture conditions for the fungus. In addition, the fungus can remain in the soil in dead insects, infecting the following generations of lesser mealworms, which use this environment to pupate (Leger, 2008; GarridoJurado et al., 2011).

A field study in laying hen houses resulted in limited action just 15 days after treatment with aqueous and granular formulations of $B$. bassiana (Geden \& Steinkraus, 2003). However, no studies for biological control of the lesser mealworm in broiler houses are known.

Thus, the laboratory and field studies reported here were conducted to assess management of lesser mealworm in broiler houses using $B$. bassiana applied as an emulsifiable oil formulation to the soil floor.

\section{MATERIALS AND METHODS}

\section{Fungal isolates}

The virulent fungal isolate of $B$. bassiana used was 'Unioeste 4' (Rhode et al., 2006), derived from the entomopathogenic fungi collection of the Agricultural Biotechnology Laboratory, UNIOESTE, Brazil. This fungus was cultured on rice in polypropylene bags. After growth, conidia were collected and formulated in $1 \%$ emulsifiable oil (oil dispersion - OD; Faria \& Wraight, 2007) at concentration of $7 \times 10^{8}$ conidia/ $\mathrm{mL}$, with a viability of $90 \%$.

\section{Testing the toxicity of the fungal isolate in the laboratory}

Lesser mealworm adults were collected from several commercial broiler houses and maintained in the laboratory in plastic containers $(50 \times 30 \mathrm{~cm}-$ diameter $x$ depth) with broiler litter and feed. Forced contact bioassays were conducted in the laboratory by immersing groups of 20 adults in $1 \mathrm{~mL}$ of the fungus formulation diluted in distilled water (concentration of $1.7 \times 10^{8}$ conidia/mL), and agitated for 10 seconds. In addition, a conidial suspension in Tween 80 solution $(0.01 \%)$ was prepared $\left(1.7 \times 10^{8}\right.$ conidia $\left./ \mathrm{mL}\right)$, and controls were prepared as emulsifiable oil (1\%) and Tween $80(0.01 \%)$ solutions in distilled water without conidia. Five groups of 20 beetles were used for each treatment and for the controls.

After immersion treatment, insects groups were transferred to Petri dishes lined with filter paper pre-moistened with distilled water and commercial poultry feed. Insects were kept in plastic containers with moistened polyurethane foam under controlled conditions (26 $\pm 2^{\circ} \mathrm{C}$ and 14-hour photophase), and evaluated daily for a period of ten days. The dead insects were removed and immersed in 70\% alcohol and distilled water solution, and individually transferred to a humid chamber to allow conidial development. Conidiogenesis on dead insects was used as confirmation of confirm fungus-induced mortality. Percent mortality was submitted to analysis of variance (ANOVA) and means were compared by Tukey's test $(p<0.05)$, using SAS statistical analysis software (SAS, 2003). The experiment was repeated three times to corroborate results.

\section{Efficacy of the formulation in the field}

Field experiments were undertaken in two commercial poultry houses in Cafelândia, State of

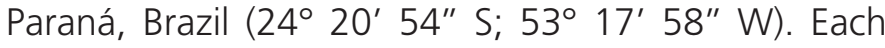


Alves LFA, Oliveira DGP, Lambkin T, Bonini AK, Alves V, Pinto FGS, Scur MC
Beauveria Bassiana Applied to Broiler Chicken Houses as Biocontrol of Alphitobius Diaperinus Panzer (Coleoptera: Tenebrionidae), an Avian Pathogens Vector

The initial assessment of the insect population before the treatment represented the total insect population in each poultry house $(100 \%)$. In the subsequent assessments in each flock, percentual variations were calculated in relation to this initial population. The efficiency of the control strategy for the lesser mealworm was calculated as reductions of the insect population initially observed (Godinho \& Alves, 2009).

\section{Molecular characterization}

Over the course of the field trials, a large amount of dead beetles, with signs of fungus infection, was found outside the treated poultry house (Aviary 1). This was atypical and was observed over the time of the trial exclusively in the perimeter of Aviary 1. Samples of these insects were collected and fungus was isolated on selective culture media (Alves et al., 1998). Molecular characterization was performed in order to identify the fungus and determine if its origin matched the one used for the treatment of the broiler house.

Two isolates obtained from samples collected in the Aviary 1 and the isolate Unioeste 4 were multiplied in Petri dishes containing Spore Production Media - ME (Alves et al., 1998) and kept at $26 \pm 2{ }^{\circ} \mathrm{C}$ and 14-hour photophase for seven days. Conidia were harvest by scrapping culture media surface and were suspended in $0.01 \%$ Tween 80 solution by vortex agitation. A suspension with $1 \times 10^{8}$ conidia/mL of each isolate was inoculated in Erlenmeyer flasks containing $150 \mathrm{~mL}$ of no-agar ME. Cultures were incubated for 72 hours at $120 \mathrm{rpm}$ and $26 \pm 1{ }^{\circ} \mathrm{C}$. The mycelium was collected from the liquid cultures, filtered using a Buchner funnel, and washed with sterile distilled water before being stored at $-20{ }^{\circ} \mathrm{C}$ prior to DNA extraction. Genomic DNA was extracted according to the methodology modified by Raeder \& Broda (1985).

The primers used in preliminary tests were based on those tested by Oliveira et al. (2011). Based on analyses of the RAPD profiles, three primers (Operon Technologies $\left.{ }^{\circledR}\right)$ were selected based on consistent band patterns (OPB-10; OPQ-05; and OPZ-19). PCR reaction mixture was prepared for a final volume of 25 $\mu \mathrm{L}[2,5 \mu \mathrm{L}$ PCR buffer $(200 \mathrm{mM}$ Tris-HCl, $\mathrm{pH} 8.8,500$ $\mathrm{mM} \mathrm{KCl}$ concentrated 10x); $1.5 \mu \mathrm{L} \mathrm{MgCl}_{2}(50 \mathrm{mM})$; $2.5 \mu \mathrm{L}$ dNTP $(2.5 \mathrm{mM}) ; 1 \mu \mathrm{L}$ of each primer $(100 \mu \mathrm{M})$; $0.2 \mu \mathrm{L}$ Taq DNA polymerase $(5 \mathrm{U} / \mu \mathrm{L})$ and $1 \mu \mathrm{L}$ DNA (20 ng)]. The amplification reactions were carried out 
using a thermal cycler (MG PTC-200) scheduled for an initial denaturation at $94{ }^{\circ} \mathrm{C}$ for $5 \mathrm{~min}$; followed by 39 cycles at $92{ }^{\circ} \mathrm{C}$ for $1 \mathrm{~min}, 35^{\circ} \mathrm{C}$ for $1 \mathrm{~min}$ and $30 \mathrm{sec}$, and $72{ }^{\circ} \mathrm{C}$ for $2 \mathrm{~min}$; and one cycle at $72{ }^{\circ} \mathrm{C}$ for $5 \mathrm{~min}$. Subsequently, the samples were analyzed in $1.4 \%$ agarose gel $(100 \mathrm{~V})$, using a $1 \mathrm{~Kb}$ Plus DNA Ladder marker (Life Technologies ${ }^{\circledR}$ ) as molecular weight pattern. Gels were stained with $10 \mathrm{mg} / \mathrm{mL}$ of ethidium bromide and photo-documented (L Pix Loccus Biotechnology).

The data obtained were analyzed using the Bionumerics software (Applied Mathematics, Kortrijk, Belgium, version 2.0). For grouping, the unweighted pair-group method was used with arithmetic mean algorithm (UPGMA) and Jaccard coefficient at a tolerance level of $3 \%$.

\section{Sequencing of rDNA-ITS region for isolate confirmation}

Amplification and sequencing of rDNA-ITS region were determined using the forward and reverse primers ITS1 (TCC GTA GGT GAA CCT GCG G) and ITS4 (TCC TCC GCT TAT TGA TAT GC), respectively (White et al., 1990). The amplification reactions were prepared for a final volume of $25 \mu \mathrm{L}$, containing 2.5 $\mu \mathrm{L}$ PCR buffer $(200 \mathrm{mM}$ Tris- $\mathrm{HCl}, \mathrm{pH} 8.4 ; 500 \mathrm{mM} \mathrm{KCl}$ concentrated 10x); $1.2 \mu \mathrm{L} \mathrm{MgCl}_{2}(50 \mathrm{mM}) ; 5.0 \mu \mathrm{L}$ dNTP $(1.5 \mathrm{mM}) ; 1 \mu \mathrm{L}$ of each primer $(50 \mathrm{mM}) ; 0.2 \mu \mathrm{L}$ Taq DNA polymerase (5 $\mathrm{U} / \mu \mathrm{L})$; and 20 ng genomic DNA, and performed in a thermal cycler (MG PTC-200). The amplification consisted of an initial denaturation at 95 ${ }^{\circ} \mathrm{C} / 3 \mathrm{~min}$, followed by 35 cycles at $94{ }^{\circ} \mathrm{C} / 1 \mathrm{~min}, 57$ ${ }^{\circ} \mathrm{C} / 1 \mathrm{~min}, 72{ }^{\circ} \mathrm{C} / 1 \mathrm{~min}$, and a cycle at $72{ }^{\circ} \mathrm{C} / 3 \mathrm{~min}$. Next, the PCR products were purified with the Wizard ${ }^{\circledR}$ SV Gel and PCR Clean-Up System kit (Promega) and the sequencing was performed with the BigDye ${ }^{\circledR}$ Terminator v 3.1 Cycle Sequencing kit on an ABI 3730 DNA Analyzer. The sequences were organized into contigs using the programs Phred (Ewing et al., 1998), Phrap (www.phrap.org), and Consed (Gordon et al., 1998), and compared with sequences in the GenBank database.

\section{RESULTS AND DISCUSSION}

\section{Efficacy in the laboratory}

Both total mortality and fungus-confirmed mortality varied from 82 to $92 \%$ for the aqueous suspension and oil-dispersion preparation, respectively. Mortality was significantly different from the water and oil controls $(F=419.9 ; C V=12.6 ; p<0.01)$ (Table 1).
Table 1 - Total and fungus-confirmed mortality of Alphitobius diaperinus adults after exposure to $1.7 \times 10^{8}$ Beauveria bassiana (Unioeste 4) conidia/mL aqueous suspension and oil dispersible formulation, over 10-day evaluation period $\left(26 \pm 2{ }^{\circ} \mathrm{C}\right.$; $\mathrm{RH}: 60 \pm 10 \%$; photophase: 14 hours).

\begin{tabular}{lcc}
\hline \multirow{2}{*}{ Treatment } & \multicolumn{2}{c}{ Mortality (\%) } \\
\cline { 2 - 3 } & \multicolumn{1}{c}{ Total } & Confirmed \\
\hline Control water & $1.0 \pm 1.0 \mathrm{~B}$ & $0.0 \pm 0.0 \mathrm{~B}$ \\
Oil Control & $3.0 \pm 3.0 \mathrm{~B}$ & $0.0 \pm 0.0 \mathrm{~B}$ \\
Unioeste 4 AS & $89.0 \pm 2.5 \mathrm{~A}$ & $82.0 \pm 4.1 \mathrm{~A}$ \\
Unioeste 4 OD & $92.0 \pm 3.4 \mathrm{~A}$ & $88.0 \pm 2.6 \mathrm{~A}$ \\
\hline C.V. $(\%)=12.6$ & & \\
\hline
\end{tabular}

Means ( \pm SEM) followed by the same letter in the column are not different by Tukey's test $(p<0.05) . A S=$ aqueous suspension; $O D=$ oil dispersible

The oil control treatment had quick and ephemeral effect on insects, causing decreased walking activity in most insects and cessation of movement. However, this effect was temporary, and the assessment after 24 hours showed that the insects were in apparently normal conditions after treatment. Similar decrease in activity was observed in the insects treated with oil dispersible fungus application.

The mortality observed with $B$. bassiana treatments were similar previous studies with the same insect (Rohde et al., 2006; Rezende et al., 2009). However, the expected higher mortality using the oil-dispersible formulation did not reach significance levels. This type of preparation is recommended to improve the performance of fungi, particularly to increase fungus resistance to high temperatures (Alexandre et al., 2006), which were limiting for the action of the fungus during the study. Despite of the similarity in the mortalities observed in the lab bioassay, the OD formulation was used in the field experiment due to other previously reported advantages (Daoust \& Roberts, 1983; Starthers et al., 1993; McClatchie et al., 1994; Batista Filho et al., 1998).

\section{Efficacy of the formulation in the field}

In pretreatment evaluations, more than 1000 adult A. diaperinus individuals were collected from each poultry house (Table 2 ). The adult beetle population in aviary 1 was significantly reduced by fungus treatment to $44 \%$ of the initial population. The treatment with B. bassiana provided long-term control of the insects, lasting over two production cycles or 150 days. However, seven months after the application, the number of adult beetles in the fungus-treated poultry house (Aviary 1) increased to values higher, but not significantly different from the original population. In contrast, in the control poultry house (Aviary 2), the 
Alves LFA, Oliveira DGP, Lambkin T, Bonini AK, Alves V, Pinto FGS, Scur MC
Beauveria Bassiana Applied to Broiler Chicken Houses as Biocontrol of Alphitobius Diaperinus Panzer (Coleoptera: Tenebrionidae), an Avian Pathogens Vector

adopted by the integrator company for poultry litter replacement or chemical insecticide application.

Field studies on lesser mealworm control using entomopathogenic fungi have been carried out in laying hen houses with applications of $B$. bassiana on the feces of the birds, achieving 60 to $90 \%$ reductions in pest populations and short persistence of 15 days (Perez et al., 1999; Geden \& Steinkraus, 2003). Despite the environmental condition differences between layer and broiler houses, the results of the present study suggest that changes in the application techniques or in formulations may improve the results of the use entomopathogenic fungi in layer houses. Long persistence and lack of risk to the poultry or human health (Haas-Costa et al., 2010) further justify the use of $B$. bassiana for the control of $A$. diaperinus in poultry production.

\section{Molecular characterization and sequencing for isolate confirmation}

Using the three RAPD markers to analyze the three isolates of $B$. bassiana obtained from aviary 1 and the isolate Unioeste 4 , bands were generated with sizes ranging from $500 \mathrm{bp}$ to $2500 \mathrm{bp}$. The minimum and maximum numbers of bands observed were two (OPQ-05) and seven (OPB-10), respectively, and the profiles generated with significant bands were virtually identical (Figure 2).

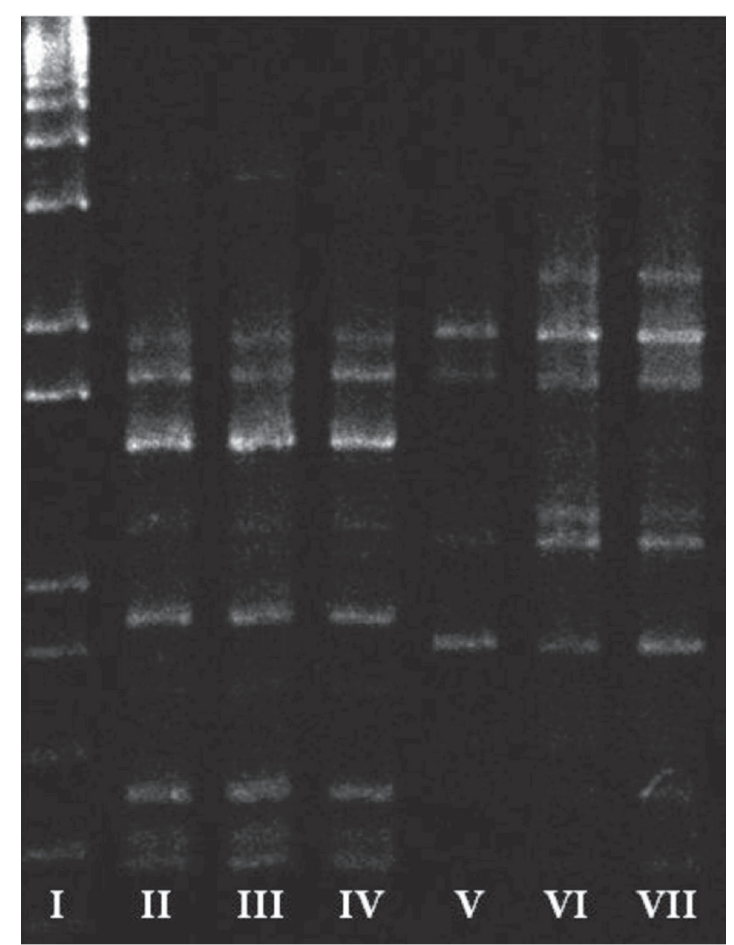

Figure 2 - RAPD profiles of Beauveria bassiana isolates: I) $1 \mathrm{~Kb}$ Plus marker; II) With OPB-10 primer Unioeste 4; III) Sample 1; IV) Sample 2; V) With OPZ-19 primer Unioeste 4; VI) Sample 1; VII) Sample 2. 
Alves LFA, Oliveira DGP, Lambkin T, Bonini AK, Alves V, Pinto FGS, Scur MC
Beauveria Bassiana Applied to Broiler Chicken Houses as Biocontrol of Alphitobius Diaperinus Panzer (Coleoptera: Tenebrionidae), an Avian Pathogens Vector
The primers ITS1 and ITS4 amplified isolate fragments with approximately $540 \mathrm{bp}$. The sequences of the fragments showed high degree of identity with Unioeste 4 isolate data in the GenBank database (EF491629).

B. bassiana naturally occurs in commercial aviaries (Alves et. al., 2005) and several studies on molecular characterization with isolates related to the lesser mealworm have been conducted (Castrillo \& Brooks, 1998; Castrillo et al., 1999; Santoro et al., 2008; Oliveira et al., 2011). No studies have reported on the re-isolation of fungi artificially produced and applied against $A$. diaperinus in field conditions. Our results confirmed the isolates obtained from Aviary 1 after used in the fungus application were the same as that applied in the treatment. Genetic confirmation that the applied isolate was the cause of fungal infections in the field eliminates natural infections as the potential cause of the mortality observed, and this was further corroborated by the fact that the dead $B$. bassianainfected $A$. diaperinus were only found after the application of the fungus.

The treatment of the aviary with the entomopathogenic fungus $B$. bassiana (isolate Unioeste 4 in oil dispersion formulation), applied to the facilities and on the soil, is an efficient method to maintain the population of $A$. diaperinus under control for up to 150 days, with a single application fact. This was confirmed by genetic typing of the applied fungal isolate as the agent causing epizootic disease in the lesser mealworm population.

\section{ACKNOWLEDGMENT}

The authors thank CNPq and Araucaria Foundation for financial support of this research and Roberto $\mathrm{M}$. Pereira (Entomology \& Nematology Dept., University of Florida) to review the manuscript.

\section{REFERENCES}

Alborzi AR, Rahbar A. Introducting Alphitobius diaperinus (Insecta, Tenebrionidae) as a new intermediate host of Hadjelia truncate. Iranian Jurnal of Parasitology 2012; 7(2): 92-98.

Alexandre TM, Alves LFA, Neves PMOJ, Alves SB. Efeito da temperatura e cama do aviário na virulência de Beauveria bassiana (Bals.) Vuill. e Metarhizium anisopliae (Metsch.) para o controle do cascudinho (Alphitobius diaperinus) (Panzer) (Coleoptera: Tenebrionidae). Neotropical Entomology 2006; 35(1):75-82.

Alves SB. Fungos entomopatogênicos. In: Alves SB, editor. Controle microbiano de insetos.. Piracicaba: FEALQ; 1998. p.289-381.

Alves SB, Almeida JEM, Moino JR A, Alves LFA. Técnicas de laboratório. In: Alves SB, editor. Controle microbiano de insetos. 2 ed. Piracicaba: FEALQ; 1998. p.637-712.
Alves LFA, Alves VS, Bressan DF, Neves PMOJ, Alves SB. Ocorrência de Metarhizium anisopliae (Metsch.) Sorok. em adultos de cascudinho (Alphitobius diaperinus) (Panzer) (Coleoptera: Tenebrionidae) em aviários comerciais em Cascavel, PR. Neotropical Entomology 2004; 33(6):793-795.

Alves LFA, Gassen MH, Pinto FGS, Neves PMOJ, Alves SB. Ocorrência natural de Beauveria bassiana (Bals.) Vuill. (Moniliales: Moniliaceae) sobre o cascudinho, Alphitobius diaperinus (Panzer) (Coleoptera: Tenebrionidae), em aviário comercial de Cascavel, PR. Neotropical Entomology 2005; 34(3):507-510.

Alves LFA, Oliveira DGP, Neves PMOJ. Fatores que afetam a eficiência da Terra de Diatomácea no controle de adultos de Alphitobius diaperinus (Panzer) (Coleoptera: Tenebrionidae). Neotropical Entomology 2008; 37(6):716-722.

Alves VM, Alves LFA, Uemura-Lima DH. Atividade da torta de nim sobre adultos do cascudinho dos aviários em condições de laboratório. Ciência Rural 2012; 42(5):888-893.

Axtell RC, Arends JJ. Ecology and management of arthropod pests of poultry. Annual Review of Entomology, 1990; 35:101-126.

Bacon CW. Effects of broiler litter volatiles and ammonia on fungal spore germination. Poultry Science 1986; 65:710-716.

Batista Filho A, Alves SB, Alves LFA, Pereira RM, Augusto NT. Formulação de entomopatógenos. In: Alves SB, editor. Controle microbiano de insetos 2 ed. Piracicaba: FEALQ, 1998. p.289-381.

Bellaver C, Costa CF, Figueiredo EAP, Jaenisch FRF, Favero JA, Palhares JCP, Fiorentin L, Brum PAR, Abreu PG, Avila VS. Boas práticas de produção de frango. Circular Técnica: Embrapa 2003; 38.

Castrillo LA, Broks WM. Differentiation of Beauveria bassiana isolates from the darkling beetle, Alphitobius diaperinus, using isozyme and RAPD analyses. Journal of Invertebrate Pathology 1998, 72(3):190-196.

Castrillo LA, Wiegmann BM, Broks WM. Genetic variation in Beauveria bassiana populations associated with the darkling beetle, Alphitobius diaperinus. Journal of Invertebrate Pathology 1999, 73(3): 269-275.

Chernaki-Leffer AM, Almeida LM, Sosa-Gómez DR, Anjos A, Vogado KM. Population fluctuation and spatial distribution of Alphitobius diaperinus (Panzer) (Coleoptera: Tenebrionidae) in a poultry house, Cascavel, Paraná states Brazil. Brazilian Journal of Biology 2007; 67(2):209-213a.

Chernaki-Leffer AM, Sosa-Gómez DR, Almeida LM. Selection for entomopathogenic fungi and $\mathrm{LD}_{50}$ of Metarhizium anisopliae (Metsch.) Sorok. for the Lesser Mealworm Alphitobius diaperinus (Panzer) (Coleoptera: Tenebrionidae). Revista Brasileira de Ciência Avícola 2007; 9:187-191b.

Chernaki-Leffer AM, Kuttel J, Martins LM, Pedroso AC, Astolfi-Ferreira CS, Ferreira F, Piantino Ferreira AJ. Vectorial competence of larvae and adults of Alphitobius diaperinus in the transmission of Salmonella enteritidis in poultry. Vector-Borne and Zoonotic Diseases 2010; 10(5):481-487.

Crawford PJ, Brooks WM, Arends JJ. Efficacy of field-isolated strains of Beauveria bassiana (Moniliales: Moniliaceae) as microbial control agents of the lesser mealworm (Coleoptera: Tenebrionidae). Journal of Economic Entomology 1998; 91(6):1295-1301.

Daoust RA, Roberts DW. Studies on the prolonged storage of Metarhizium anisopliae conidial: Effect of growth substrate on conidial survival and virulence against mosquitoes. Journal of Invertebrate Pathology 1983. $41: 161-170$

Despins JL, Axtell RC. Feeding behavior and growth of broiler chicks fed larvae of the darkling beetle, Alphitobius diaperinus. Poultry Science 1995; 74(2):331-336.

Ewing, B, Hillier L, Wendl MC, Green P. Base-calling of automated sequencer traces using phred. I. Accuracy assessment. Genome Research 1998; 8:175-185. 
Faria MR, Wraight SP. Mycoinsecticides and Mycoacaricides: A comprehensive list with worldwide coverage and international classification of formulation types. Biological Control 2007; 43:237-256.

Garrido-Jurado I, Ruano F, Campos M, Quesada-Moraga E. Effects of soil treatments with entomopathogenic fungi on soil dwelling non-target arthropods at a commercial olive orchard. Biological Control 2011; 59 (2):239-244

Gazoni FL, Wilsmann CG, Flores F, Silveira F, Bampi RA, Boufleur R, Lovato M. Efficacy of Phosphine Gas Against the Darkling Beetle (Alphitobius diaperinus). Acta Scientiae Veterinariae 2011; 39(2):1-6

Geden CJ, Arends JJ, Rutz DA, Steinkraus DC. Laboratory evaluation of Beauveria bassiana (Moniliales: Moniliaceae) against the lesser mealworm, Alphitobius diaperinus (Coleoptera: Tenebrionidae), in poultry litter, soil, and a pupal trap. Biological Control 1998; 13:71-77.

Geden CJ, Steinkraus DC. Evaluation of three formulations of Beauveria bassiana for control of lesser mealworm and hide beetle in Georgia poultry houses. Journal of Economic Entomology 2003; 96(5):16021607

Godinho RP, Alves LFA. Métodos de avaliação de população de cascudinho (Alphitobius diaperinus) Panzer em aviários de frango de corte. Arquivos do Instituto Biológico 2009; 76(1):107-110.

Goodwin MA, Waltman, WD. Transmission of Eimeria, viruses, and bacteria to chicks: darkling beetles (Alphitobius diaperinus) as vector of pathogens. Journal of Applied Poultry Research 1996; 5:51-55.

Gordon D, Abajian C, Green P. Consed: a graphical tool for sequence finishing. Genome Research 1998; 8:195-202.

Haas-Costa J, Alves LFL, Daros AA. Safety of Beauveria bassiana (Bals.) Vuill. to Gallus domesticus L. Brazilian Archives of Biology and Technology 53(2): 465-471, 2010.

Hazeleger WC, Bolder NM, Beumer RR, Jacobs-Reitsma WF. Darkling Beetles (Alphitobius diaperinus) and their larvae as potential vectors for the transfer of Campylobacter jejuni and Salmonella enterica serovar paratyphi B variant java between successive broiler flocks. Applied and Environmental Microbiology 2008; 74(22): 6887-6891.

Japp AK. Influência do Alphitobius diaperinus (Panzer, 1797) (Coleoptera, Tenebrionidae) no desempenho zootécnico de frangos de corte e avaliação da terra de diatomácea como estratégia para o seu controle. [Dissertação]. Curitiba (PR): Universidade Federal do Paraná; 2008.

Lambkin TA, Kopittke RA, Rice SJ, Bartlett JS, Zalucki MP. Distributions of lesser mealworm (Coleoptera: Tenebrionidae) in litter of a compacted earth floor broiler house in subtropical Queensland, Australia. Journal of Economic Entomology 2007; 40(4):1136-1146.

Lambkin TA, Swain AJ, Rice SJ, Bartlett JS, Zalucki MP. Field Assessments of control agents for lesser mealworm (Coleoptera: Tenebrionidae) using litter sampling. Journal of Economic Entomology 2012; 105(3): 979987.

Leger RJ. Studies on adaptations of Metarhizium anisopliae to life in the soil. Journal of Invertebrate Pathology 2008; 98:271-276.

Marcomini AM, Alves LFA, Bonini AK, Mertz NR, Santos JC. Atividade inseticida de extratos vegetais e do óleo de neem sobre Adultos de Alphitobius diaperinus Panzer (Coleoptera, Tenebrionidae). Arquivos do Instituto Biológico 2009; 76(3):413-420.

McClatchieGV, More D, Bateman RP, Prior C. Effects os temperature on the viability of the conidia of Metarhizium flavoviridae in oil formulations. Mycologycal Research 1994; 98(7):749-756.

Oliveira DGP de, Pinto FG da S, Barcellos FG, Alves LFA, Hungria M. Variabilidade genética de isolados de Beauveria spp. e virulência ao cascudinho Alphitobius diaperinus Panzer (Coleoptera: Tenebrionidae). Semina: Ciências Agrárias 2011; 32(1):147-156
Perez A, Szcypel B, Larramendy R, Acosta N, González A. Biopreparado entomopatógeno contra el coleóptero Alphitobius diaperinus. Revista Cubana de Ciência Avícola 1999; 23:45-52.

Pinto DM, Ribeiro PB, Bernardi E. Flutuação populacional de Alphitobius diaperinus (Panzer, 1879) (Coleoptera: Tenebrionidae), capturados por armadilha do tipo sanduíche, em granja avícola, no município de Pelotas, RS. Arquivos do Instituto Biológico 2005; 72(2):199-203.

Raeder U, Broda P. Rapid preparation of DNA from filamentous fungi. Letters in Applied Microbiology 1985; 1(1):17-20.

Rezende SRF, Curvello FA, Fraga ME, Reis CS, Castilho AMC, Agostinho TSP. Control of the Alphitoibus diaperinus (Panzer) (Coleoptera: Tenebrionidae) with entomopathogenic fungi. Brazilian Journal of Poultry Science 2009; 11(2):121-127.

Roche AJ, Cox NA, Richardson LJ, Buhr RJ, Cason JA, Fairchild BD, Hinkle NC. Transmission of Salmonella to broilers by contaminated larval and adult lesser mealworms, Alphitobius diaperinus (Coleoptera: Tenebrionidae). Poultry Science 2009; 88:44-48.

Rohde C, Alves LFA, Neves PMOJ, Alves SB, Silva ERL, Almeida JEM. Seleção de isolados de Beauveria bassiana (Bals.) Vuill. e Metarhizium anisopliae (Metsch.) Sorok. contra o cascudinho Alphitobius diaperinus (Panzer) (Coleoptera: Tenebrionidae). Neotropical Entomology 2006; 35(2):231240.

SAS. SAS/STAT. User's Guide. Versão 9.1.3, Cary, NC, USA. 2002/2003.

Santoro PH, Neves PMOJ, Alexandre TM, Sartori D, Alves LFA, Fungaro M. Selection of Beauveria bassiana isolates to control Alphitobius diaperinus. Journal of Invertebrate Pathology 2008; 97(2):83-90.

Santos JC, Alves LFA, Opazo MAU, Mertz NR, Marcomini AM, Pinto DGO, Bonini AK. Eficiência da aplicação de inseticida químico no solo para o Controle de Alphitobius diaperinus Panzer (Coleoptera: Tenebrionidae) em aviário de frango de corte. Arquivo Instituto Biológico 2009; 76(3):421-429.

Segabinazi SD, Flôres ML, Barcelos AS, Jacobsen G, Eltz RD. Bactérias da família Enterobacteriaceae em Alphitobius diaperinus oriundos de granjas avícolas dos Estados do Rio Grande do Sul e Santa Catarina, Brasil. Acta Scientiae Veterinariae 2005; 33 (1):51-55.

Skov MN, Spencer AG, Hald B, Nauerby B, Carstensen B, Madsen M. The role of litter beetles as potential reservoir for Salmonella enterica and thermophilic Campylobacter spp. between broiler floks. Avian Diseases 2004; 48(1):9-18

Steinkraus DC, Geden CJ, Rutz DA. Susceptibility of lesser mealworm (Coleoptera: Tenebrionidae) to Beauveria bassiana: Effects of host stage, formulation, substrate and host passage. Journal of Medical Entomology 1991; 28:314-321.

Starthers TE, More D, Prior $C$. The effect of different temperatures on the viability of Metarhizium flavoride conidia stored in vegetable and mineral oils. Journal of Invertebrate Pathology 1993; 62:111-115.

Uemura DH, Alves LFA, Opazo MAU, Alexandre TM, Oliveira DGP, Ursi MV. Distribuição e dinâmica populacional do cascudinho Alphitobius diaperinus (Coleoptera: Tenebrionidae) em aviários de frango de corte. Arquivos do Instituto Biológico 2008; 75(4):429-435.

Vittori J, Schocken-Iturrino RP, Trovó KP, Ribeiro CAM, Barbosa GG, Souza LM, Pigatto CP. Alphitobius diaperinus como veiculador de Clostridium perfingens em granjas avícolas do interior paulista - Brasil. Ciência Rural 2007; 37(3):894-896

Watson DW, Denning SS, Zurek L, Stringham SM, Elliott J. Effects of lime hydrate on the growth and development of darkling beetle, Alphitobius diaperinus. International Journal of Poultry Science 2003; 2(2): 91-96.

White TJ, Brauns T, Lee S, Taylor JW. Amplification and direct sequencing of fungal ribossomal RNA genes for phylogenetics. In: Innis, MA, Gelfand, DH, Sninsky, JJ, White TJ, editor. PCR protocols: a guide to methods and applications. New York: Academic Press; 1990. p. 315-322. 
